\title{
Uwarunkowania społeczne jakości życia rodzin z niepełnosprawnym dzieckiem
}

Niepełnosprawność jest dziś przedmiotem wielu dyskusji i badań naukowych, ponieważ stanowi poważny problem społeczny ${ }^{1}$. Czynnik ten powoduje zmiany w jakości funkcjonowania całego systemu rodzinnego, w którym dochodzi do intensywnych przeżyć wewnętrznych u wszystkich jego członków. W konsekwencji następuje zmiana w hierarchii realizowanych wartości w rodzinie, podejmowanych działań oraz wielu jej aktywności. Członkowie rodziny z niepełnosprawnym dzieckiem znajdują się w nowym położeniu, w którym wymaga się od nich modyfikacji pełnionych dotychczas ról i podejmowania złożonych decyzji.

\footnotetext{
$1 \quad$ Por. Urząd Komitetu Integracji Europejskiej, Osoby niepetnosprawne w Unii Europejskiej, Warszawa 2003, s. 2. O niepełnosprawności u osób do 16. roku życia, a więc u dzieci, mówimy wtedy, gdy mają one naruszoną sprawność fizyczną lub psychiczną o przewidywanym okresie trwania powyżej 12 miesięcy z powodu wady wrodzonej, długotrwałej choroby lub uszkodzenia organizmu, co powoduje konieczność zapewnienia im całkowitej opieki lub pomocy w zaspokajaniu podstawowych potrzeb życiowych w sposób przewyższający wsparcie potrzebne osobie w danym wieku.
} 
Niniejszy artykuł odnosi się do zagadnień dotyczących uwarunkowań społecznych jakości życia rodzin z dzieckiem niepełnosprawnym. Niepełnosprawność obejmuje różne ograniczenia funkcjonalne jednostek ludzkich w każdym społeczeństwie. Wynikają one z uszkodzenia zdolności wykonywania czynności życiowych i mają charakter stały lub przejściowy. Mogą dotyczyć sfery sensorycznej, fizycznej i psychicznej.

Przedmiotem poniższych rozważań będzie identyfikacja uwarunkowań społecznych jakości życia w rodzinie dziecka $\mathrm{z}$ niepełnosprawnością. Poprzez uwarunkowania rozumiemy czynniki wpływające na jakość życia rodziny z niepełnosprawnym dzieckiem - źródło doświadczeń społecznych zdobywanych w różnych środowiskach i sytuacjach życiowych. Każdy rodzaj niepełnosprawności dziecka staje się czynnikiem zaburzającym dotychczasowy układ w rodzinie oraz jest przyczyną dezorganizującą wcześniejszy jej styl życia.

\section{Pojęcie i istota jakości życia w kontekście osób niepełnosprawnych}

Pojęcie jakości życia wpisuje się w całokształt życia człowieka. Dotyczy tego wszystkiego, z czym człowiek spotyka się na co dzień. Podkreśla, iż jakość życia jest najważniejszą ze znanych odmian jakości².

Pojęcie „jakość życia” jest terminem wieloaspektowym, który nie posiada jednoznacznej definicji. Przez psychologów traktowana jest jako satysfakcja osobista lub poczucie szczęścia w tych dziedzinach życia, które jednostka personalnie uznaje za ważne ${ }^{3}$. Jakość życia może być również ujmowana globalnie - związana jest wtedy z oceną życia jako całości, wypracowaniem koncepcji, która pozwoli ocenić pełnię funkcjonowania jednostek ${ }^{4}$.

Przy omawianiu współczesnego podejścia do jakości życia osób niepełnosprawnych warto zwrócić uwagę na koncepcję Roberta Schalocka,

2 Por. E. Włodek, Jakość życia osób z niepełnosprawnością intelektualną w wybranych ujęciach teoretycznych, www.sosw.bochnia.pl/podstrony/publikacje/2w.pdf (15.02.2020).

3 A. Dziurowicz-Kozłowska, Wokół pojęcia jakość życia, „Psychologia Jakości Życia” $1 / 2$ (2002), s. 77.

$4 \quad$ M. Petelewicz, Jakość życia - wprowadzenie, w: Jakość życia - globalnie i lokalnie. Pomiar i wizualizacja, red. M. Petelewicz, T. Drabowicz, Łódź 2016, s. 16. 
Kennetha Keitha i Karola Hoffmana ${ }^{5}$, która uwzględnia kontekst indywidualny i społeczny, percepcję osób niepełnosprawnych przez otoczenie społeczne oraz postawy społeczne wobec nich. To model, w którym pojawia się ważny element jakości życia, związany z zabezpieczeniem oferowanym osobom niepełnosprawnym przez społeczeństwo. Jakość życia rozpatrywana jest w aspekcie zdrowia, domu oraz szkoły. Koncepcja ta łączy ją z pracą rehabilitacji, co stało się punktem zwrotnym w ewolucji tego pojęcia w kontekście osób niepełnosprawnych.

W psychologii osób niepełnosprawnych termin „jakości życia” jest słabo ugruntowany i nie ma długiej tradycji. Wzbudza jednak zainteresowanie ludzi nauki swą obszerną konceptualizacją. Jakość życia dotyczy obszarów: „ja" psychicznego, sfery wolności osobistej, różnego typu relacji międzyludzkich i złożonych aspektów życia rodzinnego ${ }^{6}$. Można ją ustalić na podstawie zbioru kryteriów przyjętych odgórnie dla wszystkich ludzi. Należą do nich: bogactwo przeżyć, poziom świadomości, aktywności, twórczości, współuczestnictwa $\mathrm{w}$ życiu społecznym. W im wyższym stopniu są one spełnione, tym wyższa jest jakość życia. Zakłada się, że parametry te u osób niepełnosprawnych związane są z zaspakajaniem potrzeb jednostki.

W zakresie pojęcia jakości życia przyjęto pogląd, który kształtuje się pod wpływem wielu czynników. Jednym z nich jest niepełnosprawność dziecka $\mathrm{w}$ rodzinie, gdyż powoduje ona zmiany $\mathrm{w}$ jakości funkcjonowania całego systemu rodziny. Do fundamentalnych założeń pojęcia jakości życia osób z niepełnosprawnością należy konstrukt społeczny rozwijany w wielu dziedzinach życia takich jak edukacja, medycyna i zdrowie psychiczne.

W medycynie ewolucja „jakości życia” doprowadziła do stworzenia nowego pojęcia: „jakości życia uwarunkowanej stanem zdrowia”, która obejmuje cztery dziedziny: stan fizyczny i sprawność ruchową, stan psychiczny, sytuację społeczną i warunki ekonomiczne, doznania somatyczne. Dlatego z medycznego punktu widzenia jakość życia opiera się na funkcjonalnej sprawności dziecka, jego możliwości samodzielnego funkcjonowania i realizowania własnych potrzeb w życiu

\footnotetext{
5 A. Firkowska-Mankiewicz, Jakość życia osób niepelnosprawnych intelektualnie Kwestionariusza Jakości Życia, „Sztuka Leczenia” 5 (1999) nr 3, s. 17-18.

$6 \quad$ Z. Dołęga, Wskaźniki jakości życia, w: Jakość życia w niepetnosprawności - mity a rzeczywistość, red. M. Flanczewska-Wolny, Kraków 2007, s. 38.

7 M. Majkowicz, R. J. Nowicki, A. Samet, Jakość życia w chorobach skóry, „Przewodnik Lekarza" 9 (2004), s. 61.
} 
Socjologowie jakość życia rozumieją jako zaspokojenie potrzeb. Pojęcie to ujmowane jest w dwóch perspektywach: obiektywnej lub subiektywnej. Perspektywa obiektywna jest zewnętrzna - obejmuje czynniki mające wpływ na sytuację ekonomiczną, warunki mieszkaniowe, środowisko naturalne, wykształcenie, wykonywaną pracę czy bariery architektoniczne. Perspektywa subiektywna jest zaś wewnętrzna - wpływa na tzw. określenie rodzaju i stopnia niepełnosprawności, poczucie jakości życia, czyli spojrzenie jednostki na jej życie, emocje i odczucia z tym związane oraz zadowolenie i poczucie sensu życia. W wypadku określania obiektywnej jakości życia człowieka, obejmującej warunki życia i dobra potrzebne człowiekowi do rozwoju i egzystencji, należy określić aktualne potrzeby jednostki oraz możliwości ich zaspokojenia. Subiektywna jakość życia odnosi się z kolei do procesów wartościowania, czyli oceny samopoczucia we wszystkich sferach jego egzystencji ${ }^{8}$.

\section{Społeczny wymiar jakości życia dziecka niepełnosprawnego w rodzinie}

Rodzina to ta podstawowa komórka społeczna, w której na świat wydawane jest potomstwo i która przyczynia się do prawidłowego rozwoju każdego dziecka, zwłaszcza niepełnosprawnego. Narodziny dziecka to ważne wydarzenie. Stanowią kamienie milowe, punkty graniczne, które nadają kształt i kierunek rozmaitym aspektom (dziedzinom) życia jednostki ${ }^{9}$. Także przyjście na świat dziecka z niepełnosprawnością rozbija w pewien sposób porządek codzienności. Powoduje daleko idące zmiany w jakości życia całej rodziny i jej otoczenia społecznego.

Dziecko postrzega się jako jednostkę posiadającą własną, odrębną i niepowtarzalną naturę, a zarazem istotę społeczną, która dąży do pełnego uczestnictwa w życiu społecznym. Społeczny wymiar życia dziecka przejawia się od najmłodszych lat i jest częścią jego ludzkiej natury, rozwijającej

8 A. Zawiślak, Jakość życia osób dorosłych z niepełnosprawnościa intelektualną, Warszawa 2011, s. 44.

9 H. Liberska i M. Matuszewska, Model rodziny z dzieckiem niepetnosprawnym, w: Rodzina z dzieckiem niepetnosprawnym - możliwości i ograniczenia rozwoju, red. H. Liberska, Warszawa 2011, s. 55. 
się pod wpływem korzystnych warunków otoczenia ${ }^{10}$. Kiedy na świat przychodzi dziecko z niepełnosprawnością, u rodziców pojawia się cały arsenał negatywnych emocji: szok, rozpacz, załamanie, panika, bezradność, poczucie krzywdy, a nawet gniew. Przeżywają oni silny stres i stoją przed koniecznością poradzenia sobie $\mathrm{z}$ tą trudną dla całej rodziny sytuacją. Zadają sobie pytania: „czy to jakaś kara?”, „dlaczego nas to spotkało?”, „dlaczego spotkało to nasze dziecko?". Małżonkowie czują się zawiedzeni, rozgoryczeni, że ich dziecko nie jest takie, jak sobie wymarzyli. Pojawia się poczucie winy, że nie zrobili wszystkiego, by przeciwdziałać kalectwu swojego dziecka. W jeszcze trudniejszej sytuacji są rodzice, których ciąża przebiegała prawidłowo, a po porodzie dowiadują się o chorobie. To moment, kiedy uświadamiają sobie, że życie z niepełnosprawnym dzieckiem wymagać będzie wielu poświęceń i wyrzeczeń, całkowicie ulegnie dezorganizacji. Zakładają, że więcej czasu będą poświęcać dziecku, rehabilitacji niżeli sobie.

Z przyjściem na świat dziecka $\mathrm{z}$ niepełnosprawnością łączą się jednak również uczucie miłości, akceptacja, współdziałanie, rozumna swoboda oraz uznanie jego praw. Rodzice akceptujący swoje niepełnosprawne dziecko:

- zdają sobie sprawę z jego upośledzenia i dostosowują wymagania do jego możliwości,

- podejmują trud rewalidacji na miarę i w kierunku dziecka,

- traktują je na równi z pozostałymi członkami rodziny,

- znają i zaspokajają potrzeby dziecka,

- przyzwyczajają je do pokonywania trudności i dążą do jego samodzielności ${ }^{11}$.

Opieka nad niepełnosprawnym dzieckiem jest trudnym zadaniem dla obojga rodziców. Wymaga ogromnego wysiłku i determinacji. Dlatego to najczęściej mama przejmuje obowiązki związane $\mathrm{z}$ wychowaniem i rehabilitacją niepełnosprawnego dziecka. Ojciec rodziny, skupiony na osiąganiu lepszych wyników w pracy zawodowej, zatroskany jest o lepsze warunki materialne i mieszkaniowe własnej rodziny. Współpraca rodziców oraz wzajemne udzielanie sobie wsparcia, zrozumienia i pomocy są bardzo ważnym elementem funkcjonowania rodziny.

Rodzina to instytucja i grupa społeczna, w której splatają się zjawiska różnej natury: biologiczne, socjologiczne, ekonomiczne, psychologiczne

10 A. Janiak, Wychowanie dziecka w pedagogii Janusza Korczaka, Lublin 20015, s. 102.
11 F. Wojciechowski, Dziecko umysłowo upośledzone w rodzinie, Warszawa 1990, s. 17. 
i pedagogiczne. Pełni ona szereg rozmaitych funkcji ${ }^{12}$ : opiekuńczą, wychowawczą, prokreacyjną oraz ekonomiczną. Opiekuńcza funkcja pociąga za potrzebę sprawowania opieki nad dzieckiem, które z racji wieku lub ograniczonej sprawności psychoruchowej, jest nie w stanie funkcjonować samodzielnie. Funkcja wychowawcza, jak sama nazwa wskazuje, jest procesem wychowawczym odbywającym się na linii rodzice-dzieci. Jej celem jest przygotowanie młodych członków rodziny do życia w społeczeństwie poprzez przekazanie im norm i zachowań służących prawidłowemu pełnieniu ról społecznych. Funkcja ta oznacza nie tylko socjalizację dzieci przez rodziców, ale również zmianę zachowań małżonków pod wpływem swoich dzieci.

Dziś rozwój dziecka z niepełnosprawnością nie jest już tematem tabu. Wręcz przeciwnie - dzieci z różnymi dysfunkcjami nie są chowane w czterech ścianach, lecz mają wiele możliwości pełnego uczestnictwa w życiu społecznym. Mimo to wychowanie dziecka z niepełnosprawnością jest niezmiernie trudnym, wyczerpującym fizycznie, psychicznie i finansowo zadaniem. Standard rodziny z niepełnosprawnym dzieckiem szczególnie się nie zmienił, ale zmieniła się ich jakość życia. Zmianie ulega sytuacja bytowa rodziny, na którą składają się warunki ekonomiczne i mieszkaniowe. To od nich zależy pozycja dziecka niepełnosprawnego i stopień zaspokojenia potrzeb jej członków. Zaprzestanie wykonywania pracy przez matkę przy niskich zarobkach ojca może znacznie obniżyć materialny standard życia rodziny. Wzrastają wydatki na leczenie i rehabilitację. Przykładem dodatkowych kosztów może być konieczność stosowania specjalistycznych, drogich leków, nierefundowanych przez budżet państwa, zachowania odpowiedniej diety, leczenia prywatnego, zakupu różnych pomocy i zabawek oraz sprzętu rehabilitacyjnego, opłacenia wynajętych rehabilitantów i terapeutów.

Ogromny wpływ na jakość życia rodziny z niepełnosprawnym dzieckiem ma przynależność społeczna. Od tego, czy jej członkowie mieszkają na wsi, w małym miasteczku czy dużym mieście, zależą jej styl życia, kapitał kulturowy i stosowane metody oddziaływań wychowawczych i socjalizacyjnych. Rodziny wychowujące niepełnosprawne dzieci na wsi i w małych miasteczkach różnią się od tych żyjących w dużych miastach przede wszystkim charakterem stosunków społecznych utrzymywanych ze środowiskiem ${ }^{13}$. Wieś

\footnotetext{
12 S. Kawula, Rodzina jako grupa i instytucja opiekuńczo-wychowawcza, w: Pedagogika rodziny, red. S. Kawula, J. Brągiel, A. Janke, Toruń 2005, s. 58.

13 I. Obuchowska, Dziecko niepełnosprawne w rodzinie, Warszawa 1991, s. 39.
} 
nadal jest środowiskiem bardziej konserwatywnym, ale częste kontakty osobiste pomiędzy jej mieszkańcami powodują, że rodzina wychowująca dziecko niepełnosprawne nie jest społecznie odrzucana.

Inaczej kształtuje się sytuacja rodziny $\mathrm{z}$ dzieckiem niepełnosprawnym $\mathrm{w}$ dużych miastach. Zanikają w nich więzi sąsiedzkie i zainteresowanie drugim człowiekiem, a kontakty międzyludzkie są mniej intensywne. Stosunek otoczenia do niepełnosprawnego dziecka i jego rodziny jest obojętny. Barierę takiej obojętności pogłębiają anonimowość, przelotność kontaktów, z czym wiąże się zanik tradycyjnych więzi sąsiedzkich. Rodzice pochodzący $\mathrm{z}$ wielkich miast poświęcają swojemu dziecku więcej czasu niż mieszkańcy wsi, którzy borykają się z nadmiarem codziennych obowiązków w gospodarstwie ${ }^{14}$. Ci drudzy najczęściej korzystają z pomocy bliskich - dziadków czy starszego rodzeństwa.

Omawiane środowiska różnią się między sobą warunkami życia, a także rozwoju, stwarzanymi niepełnosprawnym dzieciom. Mieszkający w mieście rodzice mogą znacznie więcej czasu poświęcić swemu dziecku niż mieszkańcy wsi. Kontakty międzyludzkie w miastach są zaś mniej serdeczne. Ludzie w dużym mieście często się spieszą, mają swoje sprawy i nie zwracają uwagi na innych, dlatego rodzic z niepełnosprawnym dzieckiem też ich nie zainteresuje, chyba że wyraźnie zwróci na siebie uwagę. Taką barierę obojętności i izolacji pogłębiają anonimowość, oraz przelotność kontaktów, z czym wiąże się zanik tradycyjnej więzi sąsiedzkiej oraz wzrost tolerancji dla odmiennych zachowań. Wieś z kolei nie stwarza niepełnosprawnemu dziecku tylu barier architektonicznych i komunikacyjnych co miasto. Dziecko mieszkające na wsi może pełniej uczestniczyć w życiu swej społeczności. Rodzicie $\mathrm{z}$ wielkich miast w dużym stopniu przywiązują wagę do edukacji dziecka w przeciwieństwie do rodziców pochodzących ze wsi, dla których najważniejsze jest, by ich niepełnosprawne dziecko nie sprawiało kłopotów.

14 Przeprowadzone badania $\mathrm{w}$ formie wywiadu $\mathrm{z}$ respondentami/matkami dzieci z niepełnosprawnością wskazują, że (w 70 proc.) więcej czasu poświęcają swojemu dziecku matki zamieszkujące w mieście, a (w 30 proc.) matki mieszkające na wsi stwierdzają, że w wyniku pracy w gospodarstwie poświęcają mniej czasu swojemu niepełnosprawnemu dziecku. Źródło: badania własne w formie wywiadu $\mathrm{z}$ rodzicami w gminie Zdzieszowice. 


\section{Relacje społeczne a funkcjonowanie dziecka z niepełnosprawnością}

Rodzina to naturalne środowisko dla prawidłowego rozwoju dziecka, a zwłaszcza dziecka z niepełnosprawnością. Jak już zaznaczyliśmy, pojawienie się w niej dziecka chorego ma ogromny wpływ na całą rodzinę, m.in. na relacje małżonków, rodzeństwa i społeczności. Pozytywne kontakty między nimi, pełne miłości, życzliwości i zrozumienia, zapewniają dziecku poczucie akceptacji i bezpieczeństwa. Dziecko z niepełnosprawnością funkcjonuje jednak nie tylko w otoczeniu rodziny, ale także w środowisku pozarodzinnym, które w większym bądź mniejszym stopniu determinuje jego rozwój. Narodziny chorego dziecka mogą być zaś przyczyną kryzysu jego otoczenia, rozumianego jako specyficzna reakcja doświadczającego go podmiotu, krótko- lub długotrwała, na jakieś szczególne zdarzenie albo splot zdarzeń, która może być rozpatrywana jako zjawisko rozwojowe ${ }^{15}$.

Badania wskazują ${ }^{16}$, że pogorszenie relacji małżeńskich powoduje pojawienie się negatywnych stosunków pomiędzy członkami całej rodziny, zwłaszcza dzieci i środowiska. Niepełnosprawność dziecka wpływa dezorganizująco nie tylko na relacje wewnątrzrodzinne, ale również zmienia stosunki z otoczeniem. Kontakty towarzyskie, sąsiedzkie i zawodowe ulegają osłabieniu lub zerwaniu. Często przyczyną tego stanu rzeczy są wstyd, lęk, brak czasu, pieniędzy, sił oraz chęci do uczestnictwa w życiu pozarodzinnym. Rodzice niepełnosprawnego dziecka żyją w ciągłym stresie. Na wieść o tym, że ich dziecko urodziło się z dysfunkcją, zaczynają stosować strategie obronne. Początkowo nie chcą przyjąć do wiadomości, że ich dziecko jest chore. Próbują szukać zaprzeczenia bolesnej prawdy u lekarzy, specjalistów. Trwają w rozpaczy i poczuciu bezradności, wychodzą z założenia, że dla chorego dziecka nie da się nic zrobić. Relacje rodziców dziecka niepełnosprawnego

15 H. Liberska, M. Matuszewska, Model rodziny $z$ dzieckiem niepetnosprawnym, dz. cyt., s. 56.

16 Celem podjętych badań była próba identyfikacji uwarunkowań jakości życia rodzin wychowujących dziecko z niepełnosprawnością na terenie gminy Zdzieszowice. W gminie zamieszkuje 14400 mieszkańców, w tym miasto liczy 10426 mieszkańców, a sołectwa 3974 mieszkańców. Ogółem dzieci w gminie jest 2 347, w tym 16 dzieci z niepełnosprawnością do 16. roku życia. Liczby pozyskano z danych statystycznych Powiatowego Zespołu ds. Orzekania o Niepełnosprawności w Krapkowicach. Dokonano analizy uzyskanych wyników badań pod kątem uwarunkowań społecznych w kontekście jakości życia na wsi, małych miasteczek i dużych miast. 
są obarczone stresem, który powoduje pogorszenie jakości funkcjonowania całej rodziny. Najczęściej matka rezygnuje z rozwoju zawodowego i zajmuje się nowo narodzonym dzieckiem, co może prowadzić do nieporozumień między małżonkami. Ojcowie, którzy nie potrafią pogodzić się z zaistniałą sytuacją i zaakceptować inności swojego dziecka, często angażują się w dodatkową pracę, co powoduje ich nieobecność w domu, a co za tym idzie narastające konflikty.

Są przypadki, w których niepełnosprawność dziecka bardziej wiąże rodziny, aniżeli je rozdziela. W takich domach małżonkowie mogą na sobie polegać, wspierają się w wychowaniu dziecka, zajęciach rehabilitacyjnych i terapeutycznych. Jest to jeden $\mathrm{z}$ ważniejszych czynników dla prawidłowego funkcjonowania i rozwoju dziecka. Pojawienie się dziecka z niepełnosprawnością powoduje także ograniczenie kontaktów towarzyskich jego rodziców, zmniejsza możliwość ich uczestnictwa w imprezach kulturalnych i wspólnego spędzania czasu wolnego. Małżonkowie najczęściej poświęcają go rodzinie i swojemu niepełnosprawnemu dziecku. $\mathrm{Na}$ ich emocjonalne przeżycia wpływ ma wiele czynników tj. stopień upośledzenia dziecka, ale również to, na jakim etapie pojawiła się choroba. Rodziny spotykają się $\mathrm{z}$ różnego typu problemami dzieci: od choroby ujawniającej się $\mathrm{w}$ pierwszych dniach życia (np. zespół Downa) po niepełnosprawność, która pojawiła się w wyniku choroby lub wypadku. Uświadamiają sobie, że ich dziecko może jeździć na wózku inwalidzkim. W trudniejszej sytuacji są także rodzice, którzy nie tylko przeżywają niepełnosprawność własnego dziecka, ale nie mogą zrozumieć, dlaczego jest ono wobec nich chłodne uczuciowo, unika bliskości czy przytulenia. Często czują się bezradni, dlatego potrzebują wsparcia zarówno specjalistów, jak i rodziny, przyjaciół i dalszego otoczenia. Rodzice tacy długo przeżywają negatywne emocje, które zmieniają się wraz z upływem czasu.

W skrajnych przypadkach narodziny dziecka niepełnosprawnego mogą stać się przyczyną kryzysu rodziny. Jego pojawienie się zakłóca jej związki ze środowiskiem społecznym, przekształca cały system wartości rodziców, którzy z czasem dorastają do wartości humanistycznych, takich jak miłość, wzajemny szacunek, godność osobista, poczucie bezpieczeństwa czy harmonia w życiu rodzinnym. W mniejszym stopniu przywiązują się do wartości, takich jak kariera zawodowa, sukcesy towarzyskie, bogactwo, rozrywka i sława. 
Obraz jakości życia rodziny wychowującej dziecko z niepełnosprawnością w środowisku wiejskim i małych miasteczek przekonuje nas o potrzebie wspierania rodziców i ich niepełnosprawnych dzieci. Specyfikę funkcjonowania rodzin wychowujących dziecko z zaburzeniami rozwojowymi można przedstawić w aspekcie:

- przeżyć emocjonalnych rodziców,

- stosunków ze środowiskiem społecznym,

- zmian w organizacji życia rodzinnego.

W ostatnich latach prowadzi się coraz więcej badań na temat wpływu niepełnosprawności dziecka na jego rodzinę. Gromadzone i analizowane są doświadczenia rodziców oraz rodzeństwa dzieci np. z zespołem Downa, upośledzonych umysłowo, autystycznych, niepełnosprawnych fizycznie lub przewlekle chorych. Nie można bowiem lekceważyć wpływu występujących u dziecka zaburzeń rozwoju na wszystkich członków rodziny, w tym również na rodzeństwo dziecka.

Relacje między rodzeństwem mają również ogromny wpływ na rozwój dzieci. Pojawiająca się niechęć, nietolerancja wobec niepełnosprawnego brata czy siostry, a nawet odrzucenie ze strony rodzeństwa są często powodem wielu sporów i nieporozumień w rodzinie. Problemy wynikające ze współżycia rodzeństwa w sytuacji niepełnosprawności w rodzinie nie mają negatywnego charakteru, a „inność” może mieć pozytywne znaczenie dla rozwoju zdrowego dziecka. Rodzice walczą o swoje dzieci i prawidłowe relacje w rodzinie. Również pozytywne emocje rodzica dziecka z niepełnosprawnością oddziałują korzystnie na samo dziecko i stosunki jego z innymi ludźmi w środowisku.

Poczucie wspólnoty z innymi ludźmi, w tym z członkami rodziny, nadaje sens życiu człowieka ${ }^{17}$. W procesie uspołeczniania ogromne znaczenie dla rodziny wychowującej niepełnosprawne dziecko ma integracja ze środowiskiem społecznym. Charakter związków, jakie zachodzą między rodziną a otoczeniem, uzależniony jest od powszechnie przyjmowanych poglądów na temat osób niepełnosprawnych i ich miejsca w życiu. Na wsi w procesie integracji społecznej rodzin wychowujących dziecko o zaburzonym rozwoju istotne znaczenie mają różnego typu bariery, zarówno architektoniczne

17 M. Khymko, H. Liberska, Dominujące wartości i konflikty wewnętrzne rodziców dzieci autystycznych, Rodzina z dzieckiem niepetnosprawnym - możliwości i ograniczenia rozwoju, dz. cyt., s. 183. 
i komunikacyjne, które utrudniają dziecku kontakty z rówieśnikami, jak i bariery instytucjonalne, np. brak odpowiednich placówek leczniczych, rehabilitacyjnych, przedszkoli czy szkół. Rodzice tacy szukają zazwyczaj pomocy rodziny. Wyjeżdżają do dużych miast i korzystają z opieki medycznej, konsultacji czy rehabilitacji. W dużych miastach z kolei rodzice i dzieci mają większe możliwości rozwojowe i społeczne, łatwiejszy dostęp do ośrodków rehabilitacyjnych, konsultacji pedagogów i psychologów, placówek przedszkolnych i szkolnych z oddziałami integracyjnymi, co umożliwia lepszy rozwój dziecka niepełnosprawnego.

Wiele przeżyć rodziców wywołuje pójście dziecka do przedszkola, początek nauki szkolnej oraz okres dorastania. W okresie przedszkolnym największym problemem rodziców są akceptacja dziecka ze strony rówieśników, prawidłowa diagnoza i uzyskanie pomocy specjalistycznej w zakresie rehabilitacji ruchowej, logopedycznej czy psychologicznej. Rodzice dzieci z niepełnosprawnością poszukują odpowiednich przedszkoli z oddziałami integracyjnymi, w których dziecko może się rozwijać i uspołeczniać wśród pełnosprawnych rówieśników. Nie wszystkie jednak dzieci znajdują odpowiednią pomoc i wówczas obowiązki opiekuńcze i wychowawcze przejmuje najczęściej matka. W okresie szkolnym pojawiają się nowe kłopoty związane z zaaklimatyzowaniem dziecka do nowych warunków szkolnych. Rodzice zadają sobie pytania o to, czy ich dziecko będzie akceptowane, jaki będzie stosunek rówieśników do „inności” dziecka, czy poradzi sobie ono w nowym środowisku, czy otrzyma prawidłową pomoc psychologiczno-pedagogiczną, rehabilitacyjną. Rodzice wybierają najczęściej placówki z oddziałami integracyjnymi lub szkoły specjalne, w których dziecko będzie mogło rozwijać swoje zainteresowania i zdolności wśród dzieci pełnosprawnych. Ośrodki takie z reguły znajdują się tylko $\mathrm{w}$ dużych miastach, dlatego rodzice pochodzący z wiosek przywożą dziecko niepełnosprawne do placówek w mieście.

Kolejny bardzo trudny czas zarówno dla dzieci, jak i dla rodziców, to okres dorastania. Rodzice często zadają sobie nowe pytania: „co dalej?”, jaka będzie przyszłość mojego dziecka?”, „czy możliwe jest jego dalsze kształcenie i zdobycie jakiegoś zawodu?”, „czy i gdzie można znaleźć odpowiednią szkołę"18. Pomimo dylematów i życia w stresie wielu rodziców się nie poddaje i walczy o lepszy start w przyszłość swego dziecka. Tym samym, co już wspomniano, rodzina jest środowiskiem optymalnego rozwoju dziecka

18 I. Obuchowska, Dziecko niepełnosprawne $w$ rodzinie, dz. cyt., s. 33. 
zarówno zdrowego, jak i niepełnosprawnego. Jej zadaniem jest troska o zaspokojenie biologicznych i psychologicznych potrzeb dzieci.

Warto wspomnieć także o rodzajach pomocy rodzinom dzieci z niepełnosprawnością, do których należą: pomoc medyczna, edukacyjno-rewalidacyjna i psychologiczna. Z przeprowadzonych przez nauczycieli i specjalistów rozmów z rodzicami wynika, iż większość, szczególnie tych mieszkających na wsi, słabo orientuje się w systemie funkcjonowania form pomocy, przepisach czy uprawnieniach przysługujących dzieciom i ich rodzicom. Rzadko otrzymują oni informacje od pracowników służby zdrowia, z którymi się stykają. Ich kontakty z poradnią są rzadkie, sprowadzają się głównie do diagnozy, brakuje częstych konsultacji, w trakcie których rodzice mogliby dowiedzieć się o sposobach pracy z dzieckiem ${ }^{19}$.

Rodzice, którzy z kolei mają dostęp do pomocy psychologiczno-pedagogicznej, są zadowoleni z pracy ośrodków rehabilitacyjno-wychowawczych, dziennych centrów aktywności, warsztatów terapii zajęciowej czy przedszkoli i szkół integracyjnych. Na podkreślenie zasługuje fakt, że w ostatnich latach wzrasta liczba czasopism publikujących artykuły dotyczące problemów i wychowania dzieci niepełnosprawnych. Pierwsze informacje na temat radzenia sobie z zaistniałą sytuacją część rodziców uzyskuje właśnie z nich. Badania potwierdzają, iż rodzice często czerpią ze wskazówek znajomych, którzy już korzystają z placówek oświatowych i rehabilitacyjnych ${ }^{20}$.

19 Dane uzyskano z wywiadu przeprowadzonego z matkami dzieci z niepełnosprawnością pełniącymi bezpośrednią opiekę nad dzieckiem pod kątem jakości życia rodzin żyjących w środowisku miejskim i wiejskim. W badanej grupie znalazło się dziesięć chętnych matek dzieci z różnymi rodzajami niepełnosprawności, które wykazały chęć podzielenia się problemami i radościami: troje dzieci (30 proc.) - z niepełnosprawnością narządu ruchu, $\mathrm{w}$ tym $\mathrm{z}$ afazją, dwoje (20 proc.) - z niepełnosprawnością intelektualną, dwoje (20 proc.) - $\mathrm{z}$ autyzmem, dwoje (20 proc.) - z niepełnosprawnością sprzężoną, jedno (10 proc.) - z zespołem Downa. Większość - siedem (70 proc.) - badanych rodzin mieszka w mieście. Pozostała część - trzy rodziny (30 proc.) - zamieszkuje na obszarze sołectwa. W badaniach przeważały rodziny pełne - osiem ( 80 proc.), w tym dwie (20 proc.) to matki samotnie wychowujące dziecko $\mathrm{z}$ niepełnosprawnością.

20 Respondenci, matki dzieci z niepełnosprawnością, w przeprowadzonym wywiadzie deklarowały, iż korzystają (100 proc.) z placówek oświatowych i rehabilitacyjnych. Ponadto dzieci $\mathrm{z}$ niepełnosprawnością uczestniczą $\mathrm{w}$ dodatkowych zajęciach logopedycznych (100 proc.), rewalidacyjnych (80 proc.) i rehabilitacyjnych (100 proc.) poza zajęciami odbywającymi się w ramach pobytu dziecka w przedszkolu. Dodatkowo dzieci z niepełnosprawnością (70 proc.) korzystają z turnusów rehabilitacyjnych. 
Dużymi wyzwaniami, przed którymi stoi rodzina z niepełnosprawnym dzieckiem, są radzenie sobie z codziennością pełną trudności i barier, poszukiwanie odpowiednich placówek leczenia i rehabilitacji, konieczność rezygnacji z pracy, najczęściej przez matkę, dbanie o wzajemne relacje w rodzinie, budowane we wspólnych rozmowach dzieci, męża i żony, a nawet znajdywanie czasu na relaks i pasje.

To niektóre dylematy, z którymi muszą radzić sobie rodziny wychowujące dziecko z niepełnosprawnością. Obecność dziecka chorego niesie jednak nie tylko krzyż i cierpienie, ale również radość, bezwarunkową miłość, naukę cierpliwości i empatii oraz umiejętność cieszenia się z najdrobniejszych rzeczy.

\section{Podsumowanie}

Powyższa analiza ukazała czynniki społeczne warunkujące jakość życia rodzin z niepełnosprawnym dzieckiem. Wyróżniono: zdrowie rodziny, relacje rodzinne, wsparcie rodziny, znajomych, środowiska oraz relacje interpersonalne. Pozytywna jakość życia rodzin z niepełnosprawnym dzieckiem sprzyja korzystnemu rozwojowi $\mathrm{w}$ relacjach $\mathrm{z}$ rodzeństwem, przyjaznej atmosferze, dobrym relacjom rodzinnym, prawidłowym postawom rodzicielskim, akceptowaniu przez rodziców niepełnosprawności swojego dziecka oraz wzajemnym pozytywnym relacjom rodziców. Na podkreślenie zasługuje kontakt ze środowiskiem społecznym, zwłaszcza z rówieśnikami i dalszą rodziną, które przyczyniają się do kształtowania pozytywnego obrazu siebie i nieodczuwania wstydu z powodu posiadania dziecka czy rodzeństwa z niepełnosprawnością. Rodziny wychowujące dziecko niepełnosprawne potrzebują wspierania i poznania ich potrzeb oraz oczekiwań. Uruchamianie odpowiednich środków zastępczych ułatwi takiej rodzinie udział w życiu społecznym, a odpowiednia pomoc i wsparcie podniosą jakość jej życia. Ogromną rolę w podniesieniu jakości życia osób z niepełnosprawnością odgrywa również szeroko pojęta rehabilitacja oraz integracja, która przyczynia się do dobrego funkcjonowania rodzin w społeczeństwie. Stanowi ona szansę dla prawidłowego rozwoju dziecka oraz umożliwia mu 
funkcjonowanie w naturalnym środowisku, wśród pełnosprawnych rówieśników, a także zdobywanie wiedzy i umiejętności.

$\mathrm{Na}$ osłabienie poczucia jakości życia mają wpływ czynniki zewnętrzne objawiające się jako codzienne problemy życiowe. Należą do nich: ograniczony dostęp do opieki medycznej, zwłaszcza do specjalistów, trudności w zakupie odpowiedniego sprzętu rehabilitacyjnego oraz drogich leków, konieczność przerwania lub ograniczenia pracy zawodowej przez jednego z rodziców w związku z opieką nad niepełnosprawnym dzieckiem. Badania wykazują, że jakość życia rodzin w poszczególnych jego aspektach takich jak relacje rodzinne, wsparcie innych, kariera zawodowa, relacje interpersonalne, jest niższa w rodzinach zamieszkujących wioski i mniejsze miasteczka niż tych pochodzących z dużych miast.

\section{Bibliografia}

Dołęga Z., Wskaźniki jakości życia, w: Jakość życia w niepełnosprawności mity a rzeczywistość, red. M. Flanczewska-Wolny, Kraków 2007, s. 25-40.

Dziurowicz-Kozłowska A., Wokół pojęcia jakość życia, „Psychologia Jakości Życia” 1/2 (2002), s. 77-99.

Firkowska-Mankiewicz A., Jakość życia osób niepełnosprawnych intelektualnie - Kwestionariusza Jakości Życia, „Sztuka Leczenia” 5 (1999) nr 3, s. $15-21$.

Janiak A., Wychowanie dziecka w pedagogii Janusza Korczaka, Lublin 2015.

Kawula S., Rodzina jako grupa i instytucja opiekuńczo-wychowawcza, w: Pedagogika rodziny, red. S. Kawula, J. Brągiel, A. Janke, Toruń 2005, s. 47-79.

Khymko M., Liberska H., Dominujące wartości i konflikty wewnętrzne rodziców dzieci autystycznych, w: Rodzina $z$ dzieckiem niepelnosprawnym - możliwości i ograniczenia rozwoju, red. H. Liberska, Warszawa 2011, s. 174-196.

Liberska H., Matuszewska M., Model rodziny z dzieckiem niepełnosprawnym, w: Rodzina z dzieckiem niepełnosprawnym - możliwości i ograniczenia rozwoju, red. H. Liberska, Warszawa 2011, s. 41-66. 
Majkowski W., Rodzina polska w kontekście nowych uwarunkowań, Kraków 2010.

Majkowicz M., Nowicki R., Samet A., Jakość życia w chorobach skóry, „Przewodnik Lekarza" 9 (2004), s. 60-65.

Obuchowska I., Dziecko niepetnosprawne w rodzinie, Warszawa 1991.

Petelewicz M., Jakość życia - wprowadzenie, w: Jakość życia - globalnie i lokalnie. Pomiar i wizualizacji, red. M. Petelewicz, T. Drabowicz, Łódź 2016, s. 7-32.

Włodek E., Jakość życia osób z niepełnosprawnościa intelektualna w wybranych ujęciach teoretycznych, www.sosw.bochnia.pl/podstrony/publikacje/2w.pdf (15.02.2020).

Wojciechowski F., Dziecko umysłowo upośledzone w rodzinie, Warszawa 1990. Zawiślak A., Jakość życia osób dorosłych z niepełnosprawnością intelektualną, Warszawa 2011. 
